УДК 373.3.016(07)

DOI:

Уляна Борис, кандидат педагогічних наук, викладач, Коломийського педагогічного фахового коледжу Івано-Франківської обласної ради

\title{
ФОРМУВАННЯ ЕНТОМОЛОГІЧНИХ УЯВЛЕНЬ І ПОНЯТЬ У МОЛОДШИХ ШКОЛЯРІВ НА УРОКАХ “Я ДОСЛІДЖУЮ СВІТ"
}

У статті проаналізовано особливості формування ентомологічних уявлень та понять у молодиих школярів на уроках “Я досліджую світ”. Здійснено аналіз чинних програм природничої освітньої галузі та підручників курсу “Я досліджую світ”, 1-4 клас, зметою виокремлення основних понять із теми дослідження. Розглянуто ефективні методи і прийоми формування ентомологічних уявлень $і$ понять в учнів початковоі школи на уроках “Я досліджую світ”. Зроблено висновок про необхідність інтегрованого навчання молодших школярів під час вивчення матеріалу про комах.

Ключові слова: природничі уявлення та поняття; комахи; методи та прийоми навчання; урок; екскурсія; інтегрований курс “Я досліджую світ”.

Лim. 10.

Uliana Borys, Ph.D.(Pedagogy), Lecturer, Kolomyia Pedagogical Proffecional College of the Ivano-Frankivsk Region

\section{FORMATION OF ENTHOMOLOGICAL REPRESENTATIONS AND CONCEPTS IN JUNIOR SCHOOLCHILDREN AT THE LESSONS "I EXPLORE THE WORLD"}

The article deals with the features of the formation of entomological ideas and concepts in junior high school students at the lessons "I explore the world". The author presents the analysis of the current programs of natural education and textbooks of the course "I explore the world", of the 1-4grades, in order to highlight the basic concepts of the research topic. It is noted that in the process of studying the integrated course "I explore the world" the junior student acquires the basics of natural knowledge, ideas and concepts, the teacher forms a multifaceted relationship of the child with natural and social environments and subject competencies, including environmental ones, which serve to understand and comply with the rules of environmental and conservation behavior, the formation of civic and social competencies, knowledge of yourself and the environment through observation and research, etc. Despite the diversity of research on the problem raised in the title of the article, special works, the subject of which would be the formation of primary school students' knowledge of insects, taking into account a systematic approach to their content and scope, ensuring consistency of ideas and concepts of cognitive tasks still haven 't existed yet. At the same time, acquainting younger students with the largest group of animals is an important component in forming a holistic picture of the world and relationships in nature.

Effective methods and techniques of formation of entomological ideas and concepts in primary school students in the lessons "I explore the world" are considered. The peculiarity of the formation of the students' knowledge about insects in grades 1-4 is that natural ideas and concepts are formed in integrated lessons "I explore the world". The need for integrated learning in the study of natural material is due to the fact that students form a holistic scientific picture of the natural and socio-cultural world, the relationship of man with nature. Based on the analysis of existing programs, textbooks "I explore the world" it was concluded that the basis of integration is based on the activity approach.

Keywords: natural ideas and concepts; insects; teaching methods and techniques; lesson; excursion; integrated course "I explore the world".

П остановка проблеми. У системі загальної середньої освіти початкова школа посідає важливе місце: вона є фундаментом, на якому будуються всі інші ланки цієї системи. Початкове навчання - це перший (а тому особливо відповідальний) період, у процесі якого відбувається формування навчальної діяльності дитини, період, у якому формуються основи наукового світогляду.

У початковій школі природничі уявлення та поняття формуються під час вивчення природничої освітньої галузі, у контексті інтегрованого курсу “Я досліджую світ”, де молодший школяр здобуває основи природничих знань, уявлень та понять, у нього формуються багатогранні взаємини 3 природничим i суспільним середовищами. Здобуття природничих знань учнями початкової школи надзвичайно важливе, адже вони необхідні кожній людині, щоб забезпечити їі гармонію з природою. Інтегрований навчальний курс “Я досліджую світ" спрямований на формування у школярів ключових та предметних компетентностей, зокрема й екологічної, що слугує усвідомленню та 


\section{ФОРМУВАННЯ ЕНТОМОЛОГІЧНИХУЯВЛЕНЬ І ПОНЯТЬ У МОЛОДШИХ ШКОЛЯРІВ НА УРОКАХ “Я ДОСЛІДЖУЮ СВІТ”}

дотриманню правил природоохоронної й природозбережувальної поведінки, формуванню громадянських та соціальних компетентностей, пізнанню себе і довкілля шляхом спостереження та дослідження тощо. 3-поміж компетентностей, що формуються у процесі вивчення курсу “Я досліджую світ”, - природнича, технологічна, соціальна, історична,громадянська, здоров'язбережувальна, що реалізовані у відповідних освітніх галузях Державного стандарту початкової освіти, та “виявляються в здатності учнів розв'язувати доступні особистісні та соціально значущі практичні проблеми, пов'язані з життєвими потребами учня та його суспільного життя" [1].

Аналіз останніх досліджень і публікацій. Проблема формування і розвитку знань у теорії і практиці навчання є однією із найактуальніших і складних. Саме тому протягом тривалої історії розвитку початкової природничо-наукової освіти вона була в центрі уваги багатьох учених. Зокрема, їй присвячені дослідження педагогів I. Андрущенко, Т. Байбари, О. Біди, О. Варакути, Т. Гільберг, І. Грущинської, Л. Нарочної, О. Савченко, М. Скаткіна, К. Ягодовського та інших.

Мета статті - проаналізувати процес формування елементарних ентомологічних уявлень та понять в учнів початкової школи на уроках "Я досліджую світ".

Виклад основного матеріалу. Перетворення та зміни, що відбуваються в Україні в усіх сферах життя, вимагають від кожної людини творчого підходу до своєї справи, уміння самостійно розв'язувати нові складні завдання. Освіта юного покоління українців завжди була й буде важливим показником рівня розвитку суспільства. Завданням сучасної нової української школи $\epsilon$ формування в учнів міцних знань дієвопрактичного характеру [9]. Це особливо важливо тому, що природничі знання, здобуті під час навчання в початковій школі, становлять базу для вивчення природничих дисциплін у середніх та старших класах школи. Окрім того, старшокласники використовують та вдосконалюють їх під час вивчення інших предметів у початкових класах. Проте, як свідчить практика роботи школи, значна частина молодших школярів засвоюють природничі знання формально, а тому не готові до вивчення складніших природничих понять, передбачених чинною програмою загальноосвітньої школи.

Незважаючи на різноаспектність дослідження порушеної в назві статті проблеми, спеціальних праць, предметом вивчення яких було б формування в учнів початкової школи знань про комах, ураховуючи при цьому системний підхід у формуванні їх змісту та обсягу, забезпечення послідовності процесу розвитку уявлень і понять системою різних методів та пізнавальних завдань, досі ще немає.

У початковій школі природа вивчається як єдине ціле. Важливе значення серед природничих знань, які включені до інтегрованого курсу “Я досліджую світ”, відіграють знання про тваринний світ, зокрема його різноманітність. Ознайомлення молодших школярів із найчисельнішою групою тваринного світу - важливий складник у формуванні цілісної картини світу та взаємозв'язків у природі.

Проаналізувавши зміст програми та підручників інтегрованого курсу “Я досліджую світ” (1-4 клас), можна зробити висновки про те, що інформацію про комах як представників тваринного світу, можна об’єднати в три групи: зовнішній вигляд комахи (істотна ознака), іï життєві прояви (будова тіла, характерні рухи, особливості харчування, розмноження); середовище існування, пристосування до умов життя, сезонні зміни в житті комах; різноманітність комах у природі (природніх територіальних комплексах) [8; 10].

Так, у підручниках “Я досліджую світ” авторів О. Волощенко та І. Большакової, що створені за програмою Р. Шияна, пропонується формувати уявлення про комах як представників живого світу планети. Автори підручників пропонують розглянути зовнішню будову комах, живлення, розмноження, сезонні зміни, особливості їх пристосування до навколишнього середовища. Цікавим методичним прийомом О. Волощенко є пояснення теми “Спільнота” на прикладі бджіл, у такий спосіб формуються уявлення і поняття молодших школярів про взаємозв'язок живих організмів у екосистемах. У 1-2 класі формуються такі уявлення і поняття, як “комахи”, “середовище існування”, “пристосування”, “сезонні зміни” [3; 4].

У підручниках “Я досліджую світ” Т. Гільберг та І.Грущинської, укладенихзапрограмоюО. Савченко, значна увага звертається на сезонні зміни в житті комах, їх місце в ланцюгу живлення, середовища існування (природні угруповання) та їх охорону в природі [5; 6].

У третьому класі розширюються уявлення i поняття молодших школярів про різноманітність комах у природі, місце їх існування і спосіб життя, формуються уявлення про взаємозв'язок і харчову залежність один від одного, виховується дбайливе ставлення до комах [8].

3 урахування принципів добору навчального матеріалу (науковості, доступності, систематичності 


\section{ФОРМУВАННЯ ЕНТОМОЛОГІЧНИХУЯВЛЕНЬ І ПОНЯТЬ У МОЛОДШИХ ШКОЛЯРІВ НА УРОКАХ “Я ДОСЛІДЖУЮ СВІТ"}

та послідовності) у четвертому класі навчальний матеріал розширюється і поглиблюється. Учні повинні розуміти, що комахи посідають особливе місце в системі органічного світу. У курсі “Я досліджую світ” молодші школярі вивчають тваринний світ материків та океанів, природних зон України.

Успішному засвоєнню знань про комах сприяє правильний добір методів та прийомів навчання. Відомо, що лише правильно дібрані методи навчання, які відповідають змістові навчального матеріалу і віковим особливостям учнів молодшого шкільного віку, забезпечують ефективне засвоєння знань, підвищують їх якість та ефективність, підсилюють його виховну функцію. Так, до прикладу, спостереження як найважливіший метод пізнання тваринного світу характеризується низкою особливостей: а) його можна організувати на уроках-екскурсіях, де навколишнє середовище є природним для комах; б) дає змогу спостерігати особливості процесів життєдіяльності, розвитку і поведінки комах, які стають об'єктами тривалого вивчення.

Планувати спостереження учитель повинен 3 урахуванням вимог, відповідно до типових освітніх програм та методики щодо його організації та проведення:

- необхідно заздалегідь визначити місце спостереження, знайти типове для тої чи тої комахи середовище існування;

- спостереження не повинно завдавати шкоди комасі (привести до її загибелі, зміні місця існування, руйнування іiі житла тощо);

- у процесі спостереження потрібно враховувати особливості конкретного представника групи комах (величину, характер руху). Це є підставою для планування індивідуальних, групових чи фронтальних спостережень;

- цілеспрямованість спостереження і зміст супровідної бесіди багато в чому визначаються характером проявів комах у цей час. Тому вчитель окреслює заздалегідь лише план уроку-екскурсіі, успіх якого буде залежати від його педагогічної майстерності та спостережливості. Розв'язуючи основне завдання цього спостереження, варто звернути увагу дітей і на несподівані моменти в поведінці комах (задля безпеки життєдіяльності учнів).

Формування уявлень та понять учнів 1-2 класу про комах під час спостережень доцільно починати з метелика та мурашки (молодші школярі добре знайомі з ними з дошкільного віку), які $є$ найбільш контрастними представниками свого класу, мають яскраво виражені особливості зовнішньої будови і способів пересування. Діти розглядають мурашку і метелика (павине око, лимонницю), роблять власні висновки й узагальнення. Цікаво провести порівняльні спостереження за метеликом і мурашкою, якщо обидві комахи перебувають в інсектарії.

Відомі учням комахи доцільно порівнювати 3 менш знайомими, до прикладу, метелика 3 бабкою. Діти знаходять подібність у їх будові, частинах тіла і в способі пересування. Такий характер спостереження готує учнів до розв'язання у майбутньому більш складного розумового завдання - виокремлення загальних ознак у комах, встановлення зв'язків між зовнішньою будовою і способом життя, харчуванням та середовищем їх існування [5].

Формуючи в третьокласників уявлень про зовнішній вигляд комах, можна добирати для спостереження інших представників цього класу, наприклад, хруща і сонечко семикрапкове. Опираючись на засвоєні на попередніх уроках знання, необхідно формувати нову мету та завдання: збагачувати уявлення учнів про користь комах, розвивати здатність класифікувати тварин на групи за істотними ознаками.

Під час вивчення теми "Комахи” у 1-4 класі словесні методи найчастіше застосовуються на етапі сприймання і усвідомлення учнями нового матеріалу під час його викладу задля розвитку пізнавальної активності, логічного мислення школярів і засвоєння ними інформації, що викладає учитель. За характером виклад матеріалу може бути описовим, пояснювальним, проблемним. На практиці він реалізується у формі бесіди, розповіді, опису, пояснення у межах загальних методів навчання - пояснювально-ілюстративного або частково-пошукового.

Наочні методи навчання передбачають застосування ілюстрацій і демонстрацій з метою досягнення ясності та доказовості словесних пояснень вчителя. У процесі вивченні теми “Комахи" застосовуються моделі як засоби наочності, при цьому відбувається наочно-чуттєве ознайомлення учнів із будовою комах, їх різноманітністю в природі тощо. Наочність, використана на уроці, може бути натуральною i зображувальною. Під час застосування наочних методів джерелом інформації стають живі об'єкти, а також кінофільми, таблиці, роздаткові картки, які дають уявлення молодшим школярам про будову, цикл розвитку та різноманітність комах у природі.

Учням початкової школи важко зрозуміти цикл розвитку комах у природі, тому для кращого засвоєння цієї теми варто продемонструвати навчальні відео. Навчальне кіно має велике 


\section{ФОРМУВАННЯ ЕНТОМОЛОГІЧНИХУЯВЛЕНЬ І ПОНЯТЬ У МОЛОДШИХ ШКОЛЯРІВ НА УРОКАХ “Я ДОСЛДЖУЮ СВІТ”}

значення для утворення уявлень на початковій стадії вивчення навчального матеріалу. Однак кінофільм може застосовуватись не тільки на початковій стадії вивчення матеріалу. Навчальний фільм / мультфільм чи презентаційні матеріали можуть дати відповідь на низку запитань: як розмножуються комахи? які бувають комахи в природі? чому потрібно берегти комах у природі? та ін. Демонстрування кінофільмів сприяє встановленню логічних зв'язків у навчальному матеріалі, допомагає учням систематизувати факти, виокремити істотне [2].

Практичні методи становлять складну взаємодію слова, наочності й практичної роботи, яку організовує вчитель з метою розвитку думки учнів. В ії основі лежить практична діяльність школярів, яка здійснюється за участі керівного слова вчителя та засобів наочності. Одним із видів практичної діяльності на уроках курсу “Я досліджую світ" є виготовлення лепбука - це спільна діяльність педагога та учнів, під час якої діти запам'ятовують важливу інформацію. Цьому передують тематичні уроки та ігри. Такий вид роботи вчить молодших школярів обробляти й систематизувати інформацію, допомагає краще iï запам'ятати. Окрім того, у них розвиваються творчі здібності і підтримується інтерес до навчання. Лепбуки можна створювати як індивідуально, так і в парі чи групі. Цей вид діяльності допомагає школярам за їніми бажаннями дібрати інформацію 3 теми, що вивчається, і краще зрозуміти та запам'ятати матеріал. Також це чудовий спосіб для повторення вивченого. Створення лепбука може бути ще й формою представлення підсумків проєкту або завершення вивчення теми.

Ефективним прийомом навчання $є$ “Діаграма Вена”. Цю методику найкраще використовувати для порівняння двох понять або предметів. Ї̈̈ можна зобразити за допомогою схеми: два кола, що перетинаються між собою. Кожне коло означає окреме поняття, місце перетину - це спільні властивості обох понять. За допомогою цієї діаграми можна порівнювати об'єкти та явища природи. До прикладу, молодші школярі часто припускаються помилки, вважаючи, що павук це комаха, тому для пояснення доречно застосувати “Діаграму Вена".

Жоден із розглянутих методів та прийомів навчання не можна вважати універсальним i придатним для розв'язання всіх завдань, що постають перед учителем у процесі викладання курсу “Я досліджую світ”. Тому під час підготовки до цих уроків вчителеві необхідно пам'ятати, що добір і оптимальне поєднання методів, прийомів і засобів повинні розв'язувати завдання - навчання, розвитку і формування особистісних якостей школяра.

Висновки та перспективи подальших досліджень. Особливістю формування знань про комах у 1-2 класах є те, що природничі уявлення та поняття формуються на інтегрованих уроках “Я досліджую світ”. Необхідність інтегрованого навчання під час вивчення природничого матеріалу зумовлюється тим, що в молодших школярів формується цілісна наукова картина природного й соціокультурного світу, взаємин людини з природою. На основі аналізу чинних програм, підручників “Я досліджую світ” можна зробити висновок про те, що в основу інтеграції покладено діяльнісний підхід.

Наскрізно інтеграція семи освітніх галузей простежується в типовій освітній програмі Р. Шияна та підручниках, орієнтованих на НУШ2, а непрямі інтегровані зв'язки - під час вивчення мовно-літературної галузі в процесі формування звука ДЖ (джміль), букви Х (мураха), звукобуквеного аналізу слів: бджола, комар, метелик, джміль, роботі над віршами, оповіданнями, казками, прислів'ями тощо.

На уроках “Я досліджую світ” під час формування знань про комахи застосовуються математична непряма інтеграція. У кожному класі необхідно розв'язувати задачі на основі числових даних, узятих безпосередньо із навколишнього життя. Результати спостережень дають багатий матеріал для усного рахунку. Отже, взаємозв'язок математики і природознавства, української мови та природознавства сприяє осмисленню наявних знань, розвитку логічного мислення, поглибленню розуміння причиннонаслідкових зв'язків. Знайомство 3 природою проводиться не тільки на уроках, але і в повсякденному житті. Спостереження, урокиекскурсії, розгляд ілюстрацій, читання книг про комах і дидактичні ігри - усі заходи в комплексі повинні забезпечити успішність роботи вчителя. При цьому важливо здійснювати взаємозв'язок повсякденної роботи і обов'язкових занять. Вона може бути різною. Спостереження за комахами під час прогулянки, читання книг, які зацікавили дітей, дають поштовх для поглибленого аналізу на уроках, і навпаки, та чи та тема, розпочата на уроці, розширюється і конкретизується у подальшій повсякденній роботі.

Подальших досліджень вимагають питання підготовки майбутнього вчителя початкової школи до формування ентомологічних уявлень $\mathrm{i}$ понять у молодших школярів на уроках “Я досліджую світ". 


\section{ФОРМУВАННЯ ЕНТОМОЛОГІЧНИХУЯВЛЕНЬ ІПОНЯТЬ У МОЛОДШИХ ШКОЛЯРІВ НА УРОКАХ “Я ДОСЛІДЖУЮ СВІТ”}

\section{ЛІТЕРАТУРА}

1. Андрусенко I. Підручник “Я досліджую світ” як засіб формування екологічної грамотності молодших школярів. Проблеми сучасного підручника. 2019. № 22. URL: http://ipvid.org.ua/ u p 1 o a48f28fb355fcbc66405c26ccb16706b.pdf

2. Байбара Т.М.Методика навчання природознавства в початкових класах. Київ: Веселка, 1998. 325 с.

3. Волощенко О., Козак О., Остапенко Г. “Я досліджую світ” для 2 класу. Частина 1 (у 2-х частинах). Київ: Оріон, 2019. 144 с.

4. Волощенко О., Козак О., Остапенко Г. “Я досліджую світ” для 2 класу. Частина 2 (у 2-х частинах). Київ: Оріон, 2019. 146 с.

5. Гільберг Т., Тарнавська С., Хитра 3., Павич Н. Навчально-методичний посібник "Нова українська школа: методика навчання інтегрованого курсу “Я досліджую світ” у 3-4 класах закладів загальної середньої освіти на засадах компетентнісного підходу". Київ: Генеза, 2020. 240 с.

6. Гільберг Т., Тарнавська С., Павич Н. Я досліджую світ: підручник для 2 класу закладів загальної середньої освіти (у 2-х частинах): Ч.1 Київ: Генеза, 2019. 144 с.

7. Грущинська I. В., Хитра 3. М. Я досліджую світ: підручник для 2 класу закладів загальної середньої освіти (у 2-х частинах): Ч.1. Київ: УОВЦ “Оріон”, 2019. 144 c.

8. Навчальні програми для початкової школи. 2016. URL: http://osvita.ua/school/program/8793/.

9. Нова українська школа. URL: https:// mon.gov.ua/storage/app/media/zagalna\%20serednya/ nova-ukrainska-shkola-compressed.pdf

10.Типові освітні програми для закладів загальної середньої освіти: 1-2 класи та 3-4 класи. 2019. Київ: Світоч, 2019. 240 с.

\section{REFERENCES}

1. Andrusenko, I. (2019). Pidruchnyk "Ia doslidzhuiu svit" yak zasib formuvannia ekolohichnoi hramotnosti molodshykh shkoliariv [Recipient "I investigate the world" as a means of forming environmental literacy of young schools]. Problems of the modern textbook. No. 22. Available at: http:/ / i p vid . org.ua/up load/iblock/a 48 / a48f28fb355fcbc66405c26ccb16706b.pdf. [inUkrainian].
2. Baibara, T. M. (1998). Metodyka navchannia pryrodoznavstva $\mathrm{v}$ pochatkovykh klasakh [Methods of teaching science in primary school]. Kyiv, 325 p. [in Ukrainian].

3. Voloshchenko, O., Kozak. O., \& Ostapenko, H. (2019). "Ia doslidzhuiu svit" dlia 2 klasu [I explore the world: a textbook for the 2nd grade]. Part 1 (in two parts). Kyiv, 144 p. [in Ukrainian].

4. Voloshchenko, O., Kozak, O., \& Ostapenko, H. (2019). "Ia doslidzhuiu svit" dlia 2 klasu [I explore the world: a textbook for the 2nd grade]. Part 2 (in two parts). Kyiv, 146 p. [in Ukrainian].

5. Hilberh, T., Tarnavska, S., Khytra, Z., \& Pavych, N. (2020). Navchalno-metodychnyi posibnyk "Nova ukrainska shkola: metodyka navchannia intehrovanoho kursu "Ia doslidzhuiu svit" u 3-4 klasakh zakladiv zahalnoi serednoi osvity na zasadakh kompetentnisnoho pidkhodu" [Textbook "New Ukrainian school: methods of teaching an integrated course "I explore the world" in 3-4 grades of general secondary education on the basis of competence approach"]. Kyiv, 240 p. [in Ukrainian].

6. Hilberh, T., Tarnavska, S. \& Pavych, N. (2019). Ya doslidzhuiu svit: pidruchnyk dlia 2 klasu zakladiv zahalnoi serednoi osvity (u 2-kh chastynakh) [I explore the world: a textbook for the 2 nd grade of general secondary education (in 2 parts)]: Part. 1 Kyiv,144 p. [in Ukrainian].

7. Hrushchynska, I. V. \& Khytra, Z. M. (2019). Ya doslidzhuiu svit: pidruchnyk dlia 2 klasu zakladiv zahalnoi serednoi osvity (u 2-kh chastynakh) [I explore the world: a textbook for the 2 nd grade of general secondary education (in 2 parts)]: Part.1. Kyiv, 144 p. [in Ukrainian].

8. Navchalni prohramy dlia pochatkovoi shkoly (2016). [Curricula for primary school]. Available at: http://osvita.ua/school/program/8793/. [in Ukrainian].

9. Nova ukrainska shkola (2018). [New Ukrainian School]. Available at: https://mon.gov.ua/storage/app/ media/zagalna $\% 20$ serednya/nova-ukrainska-shkolacompressed.pdf [in Ukrainian].

10. Typovi osvitni prohramy dlia zakladiv zahalnoi serednoi osvity: 1-2 ta 3-4 klasy (2019). [Typical educational programs for general secondary education: $1-2$ and 3-4 grades]. Kyiv, 240 p. [in Ukrainian].

Стаття надійшла до редакції 19.11.2021

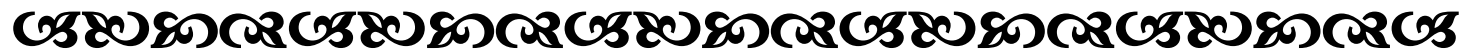

“Виховання є мистечтвом, використання якого зростатиме протягом багатьох поколінь". 